\title{
Building Materials and Heat Insulators.
}

T HE Department of Scientific and Industrial Research has issued two special reports on floors and thin walls, the result of work undertaken by an $a d$ hoc Building Materials Research Committee appointed to investigate new materials and constructional methods in connection with housing schemes (H.M. Stationery Office, $1 s .3 d$. net and $6 d$. net respectively). Some eight types of floors were dealt with, comprising hollow tiles, brick and tile, reinforced concrete, ash concrete, and ordinary wood joists. Suitable sections or units of these floors were erected and tested for carrying capacity to destruction. The results are summarised in tabular form, showing the weight of the floor, load carried, deflection, breaking load, age on testing, elastic limit, and so on. These results are also plotted diagrammatically, and drawings are given showing the construction of each floor to scale. The ash concrete proved weak, and the ordinary joisted floor, though possessing obvious disadvantages from some aspects, appeared to hold its own in the matter of strength. The experiments on thin walls included the testing of brick and concrete blocks and slabs and coke-breeze materials. Consistent results showed that the crushing strength of the walls varied from 67 to 83 per cent. of that of cubes of the materials respectively employed. Lengths of wall of 14 in. and $3 \mathrm{ft} .6 \mathrm{in}$. and $2 \frac{5}{8}$ in. to $4 \frac{2}{2}$ in. thick were dealt with. These strips were $8 \mathrm{ft}$. 6 in. high, and the horizontal pull necessary to make the wider strips collapse was measured. The materials built in lime mortar on account of early failure under test give rise to criticism of lime as a binding agent, but surely the behaviour of walls so built after only twenty-four days cannot be fairly compared with that of similar walls built in cement which sets in a day or two. Lime was used in all our national buildings until comparatively recent years; it is cheaper in actual cost and labour than cement, and its wider use merits revival. These experiments are valuable and interesting; it has to be remembered, however, that the country builder usually fears new methods, and is apt to put unduly high prices on unknown forms of construction.

The fifth special report of the Food Investigation Board, issued by the Department of Scientific and Industrial Research, consists of an account of experiments on heat insulators suitable for use in cold stores. The work has been carried out at the National Physical Laboratory by Dr. Ezer Griffiths, and so far has been devoted to the determination of the thermal conductivity of a number of materials adapted to lowtemperature insulation. In the experiments a warm surface, consisting of a metal plate electrically heated, was maintained at a steady temperature and placed opposite to a similar plate cooled by brine circulation, the material under test filling the space between the two plates. Special precautions were taken to eliminate errors arising from edge effects in the warm plate and air convection in the material, and when a steady temperature had been attained in both plates the heat passing through the lagging was deduced by measuring the watts furnished to the warm plate. The results obtained show that the conductivity in C.G.S. units for slab cork is o.ooor I ; granulated cork, 0.000 I I to 0.00019 ; slag wool, 0.000102 ; and dry charcoal, 0.000122. A number of other substances giving higher values were also tested, and mention is made of a cellular form of rubber which from preliminary tests appears to be superior to any other material examined, its conductivity being about 0.000085 . As an appendix to the report; a description is given of the apparatus devised by Dr. Griffiths for determining the specific heats of the materials under notice. Although other factors, such as moisture absorption and liability to organic growths, have to be taken into account in choosing a lagging for a cold store, the figures obtained by Dr. Griffiths should prove of much practical value to those engaged in the refrigerating industry.

\section{Industrial Fatigue.}

$\mathrm{T}$ Industrial Fatigue Restarch Board, which has recently been reconstructed as an advisory body under the Medical Research Council, is to be congratulated upon the publication of . two highly valuable and most interesting reports. These are doubtless a legacy to it from the older Board the wider sphere and greater liberty of action of which were recently brought to an end by the Treasury under the pretext of economy. They are published by H.M. Stationery Office at $I s$. and $2 s$. respectively, Report No. I $_{2}$ being on vocational guidance and Report No. I $_{5}$ on motion study in metal polishing. The former of these reports, written by Mr. B. Muscio (who has since accepted a professorship in the University of Sydney), gives a detailed review of the literature on vocational selection. The list of nearly sixty books and papers at the end of the report indicates the diligence which the author has brought to bear on his task. The report is divided into three sections: (I) introductory, (2) summary of special investigations, and (3) future investigations. The second section, filling forty-two of the fifty-seven pages, contains a most able and critical account of the psychological tests that have been applied to clerical, engineering, and metallurgical occupations, music, printing, salesmanship, telegraphy, telephone exchange work, transport work, war experiments, etc. Prof. Muscio indicates in his last section the wide field which is now open for future investigations conducted on a broader scale and on a more systematic basis than hitherto.

Not less valuable is the Board's Report No. I5 on motion study in metal polishing by Messrs. E. Farmer and R. S. Brooke. These investigators prove very conclusively what an enormous wastage of effort now occurs in the "buffing" (spoon and fork polishing) trade owing to the lack of a systematic course of training for newly entering workers. They indicate the principles on which such a course should be based, and give data derived from the actual application of those principles, which "prove conclusively that a beginner, given adequate training, can become an expert dollier within a very few days, but left to herself, without proper instruction, she probably will never become highly skilled, and will continue all her life to waste her energy in unnecessary and unproductive movements." The influence of fatigue was ingeniously studied by means of a recording wattmeter which they applied to the machines employed for removing scratches and other imperfections from spoons and forks. It was found that as towards the end of the day the girls' output diminished and their

NO. 2729 , VOL. IOg] 
fatigue increased, they tended to give more vigorous and more numerous strokes, to pause longer between each stroke, and to take a longer time over each stroke. In other words, Messrs. Farmer and Brooke 'prove that the tired "rougher" is "not only working slower than when she is fresh. but is also expending her energy extravagantly."

\section{University and Educational Intelligence.}

LonDon.-The Franks research studentship in archæology, value Iool. for one year, is offered. Applications must reach the Academic Registrar, the University of London, South Kensington, S.W.7, by, at latest, March 2.

SHEFFIELD. - The council of the University has made the following appointments :- Mr. Douglas Hay to be professor of mining; Mr. A. J. Saxton, assistant lecturer in physics; Mr. L. W. Cole, assistant lecturer and demonstrator in botany; Mr. H. W. Southgate, lecturer in pharmacology; Dr. E. F. Finch and Mr. V. Townrow, assistant curators of the Pathological Museum; and Dr. A. G. Yates, demonstrator in medical pathology.

LAST year the Civic Education League organised a very interesting Easter visit to Belgium for the purpose of civic study. This year a similar visit to Holland is being arranged. Anyone interested in civic studies may join the party, and early application to Miss Margaret Tatton, secretary, Civic Education League, Leplay House, $6_{5}$ Belgrave Road, S.W.I, should be made. Members of the party will have special facilities for first-hand contact with the work and personnel of the chief social and economic institutions of the country.

THE annual prize distribution at the Sir John Cass Technical Institute, Aldgate, E.C.3, was held on Wednesday, February 8 , when the prizes were distributed by Prof. William Rothenstein, principal of the Royal College of Art. The chairman of the governing body, the Rev. J. F. Marr, in giving a summary of the work of the institute during the past session, stated that the increase in the number of students had been more than maintained, and that the capacity of the institute, especially in the science departments, had been taxed to the utmost. Twenty students had been engaged in research work during the session, and the total number of investigations published from the institute had now reached II5. The Department of Petroleum Technology, which was initiated at the commencement of the present session, is one of the institute's most important developments, and there were already I5o students in attendance. Representatives of the industry have acted as a consultative committee to advise the governors in respect to the courses of study which have been provided, and the chief oil companies of the London area have given generous support towards the equipment and maintenance of the depart. ment. In the course of an address on "Education and Industry " Prof. Rothenstein said he regarded every kind of education as something in the nature of a pursuit after truth. Whereas there was much liphomage to science and art and the crafts by our merchant princes and captains of industry, these employers did not have the same faith in them as their employees. Commercial men in past civilisations somehow knew how to ask for the best, but that was not true of our own civilisation. What we required was a standard of commerce which knew how to utilise what was best in the arts and sciences, for he refused to believe that people, in general, did not value that which was good and beautiful in production. NO. 2729 , VOL. IO9]

\section{Calendar of Industrial Pioneers.}

February 16, 1890. William Jarvis McAlpine died.Trained under Jervis, the chief engineer of the Delaware and Hudson Canal, McAlpine became State Engineer for New York, and was also State Railroad Commissioner. At the request of the Austro-Hungarian Government he prepared plans for the improvement of the Danube. He was the first American to become a member of the Institution of Civil Engineers, and in $\mathbf{I} 886$ was president of the sister institution in the United States.

February 18, 1888. Thomas Turner Tate died.-In conjunction with Sir William Fairbairn, Tate was the author of memoirs on the vapour tension of superheated steam and on the strength of materials in relation to the construction of iron ships, and was the inventor of the double piston air-pump. For some years he was mathematical master at Battersea Train ing College, and was known for his educational works.

February 19, 1816. Jean Pierre François Guillot Duhamel died.-An early student at the Ecole des Ponts et Chaussées, Duhamel accompanied Grabriel Jars in his extended industrial tour throughout Europe, and on his return to France did much to improve the manufacture of steel. He afterwards became Government Inspector of Forges and Furnaces, a professor of metallurgy at the Ecole des Mines, and a member of the Paris Academy of Sciences.

February 20, 1825. Joseph Marie François Cachin died. -One of the most distinguished French civil engineers of his day, Cachin was intimately connected with the improvements of the harbour of Cherbourg, and in I820 published his "Mémoire sur la digue de Cherbourg comparée au breakwater, ou jetée, de Plymouth."

February 20, 1826. Matthew Murray died.-With Fenton and Wood, Murray founded a mechanica engineering works at Leeds which became one of the rivals of Boulton and Watt. The firm built flaxmaking machinery and constructed some of the earliest Blenkinsop locomotives, and Murray is generally credited with the invention of the short D-slide valve for steam engines.

February 20, 1913. Sir William Arrol died.-The builder of many famous bridges, Arrol between $\mathrm{x} 88_{2}$ and 1887 reconstructed the viaduct over the Firth of Tay, and between $\mathrm{I} 883$ and $\mathrm{r} 890$ built the Forth Bridge. This bridge, designed by Fowler and Baker, has always been regarded as one of the greatest engineering structures in the world. With a total length of $8295 \mathrm{ft}$., of which the three cantilevers account for $5349 \mathrm{ft}$., the bridge contains $5 \mathrm{I}, 000$ tons of steel, while the towers rise to a height of $360 \mathrm{ft}$ and the line is carried $150 \mathrm{ft}$. above the water at high tide. Arrol was knighted at the opening of the bridge by Edward VII.

February 21, 1888. George Henry Corliss died.-.'The greatest steam-engine builder of America, Corliss about 1848 entered into partnership with Nightingale at Providence, Rhode Island. Adopting the trip gear of Sickells, he brought out the Corliss form of steam engine, which on account of its improved economy and regular turning movement became known ail over the world.

February. 21, 1912. Osborne Reynolds died.-For nearly forty years professor of engineering at Owens College, Manchester, Reynolds made many investigations of importance to engineers and shipbuilders, such as those on screw propulsion, the flow of liquids, the condensation of steam, the transmission of heat, and lubrication. He was the inventor of the compound turbine.

E. C. S. 